\title{
Comparative evaluation of triplet antiemetic schedule versus doublet antiemetic schedule in chemotherapy-induced emesis in head and neck cancer patients
}

\author{
Pulkit Kaushal $^{1}$, Rajeev Atri $^{2}$, Abhishek Soni $^{2}$ and Vivek Kaushal ${ }^{2}$ \\ ${ }^{1}$ Department of Psychiatry, Seth GS Medical College and KEM Hospital, Mumbai 400012, Maharashtra, India \\ ${ }^{2}$ Department of Radiotherapy, Pt. B. D. Sharma Post Graduate Institute of Medical Sciences, Rohtak 124001, Haryana, India
}

Correspondence to: Pulkit Kaushal. Email: p.kaushal@rediffmail.com

\begin{abstract}
Purpose: To compare the antiemetic combination of palonosetron, dexamethasone, and aprepitant (PDA) with antiemetic combination of ondansetron and dexamethasone (OD) in head and neck cancer patients receiving docetaxel, carboplatin, and 5-FU based chemotherapy.

Methods: Sixty previously untreated patients were randomly divided into two groups of thirty patients each. The PDA group received a combination of palonosetron $0.25 \mathrm{mg}$ intravenously (IV), dexamethasone $12 \mathrm{mg}$ IV, and capsule aprepitant per oral. OD group received ondansetron $16 \mathrm{mg} \mathrm{IV}$, and dexamethasone $12 \mathrm{mg}$ IV for emesis control. The primary objective was to compare the efficacy of two antiemetic schedules for preventing acute and delayed CINV (chemotherapy-induced nausea and vomiting). The primary efficacy end point was complete response (CR).
\end{abstract}

Results: All the patients tolerated both schedules well. The antiemetic response for acute emesis (first 24 hours) in PDA versus OD group was: CR was 86.7 versus $60 \%$. For delayed emesis (from day $2-5$ ) in PDA versus OD group CR was 83.3 versus $53.3 \%$. The intensity of acute nausea (first 24 hours) in PDA versus OD group was: no nausea-70 versus $46.6 \%$. The intensity of delayed nausea (from day $2-5$ ) in PDA versus OD was: no nausea-76.6 versus $43.3 \%$. The CR to both acute and delayed emesis (no vomiting from day $1-5$ ) in PDA versus OD group was 83.3 versus $53.3 \%$ ( $p<0.05$, significant). The CR to nausea (no nausea from day $1-5$ ) in PDA versus OD group was 70 versus $43.3 \%$ ( $p<0.05$, significant).

Conclusion: Although both the schedules were tolerated well, the PDA schedule (palonosetron, aprepitant, and dexamethasone) was significantly better than the OD schedule (ondansetron and dexamethasone) in controlling cancer CINV in the acute as well as delayed phases.

Keywords: aprepitant, antiemetic, CINV (chemotherapy-induced nausea and vomiting), head and neck cancer, palonosetron

Published: 25/08/2015

Received: 29/03/2015

ecancer 2015, 9:567 DOI: 10.3332/ecancer.2015.567

Copyright: (c) the authors; licensee ecancermedicalscience. This is an Open Access article distributed under the terms of the Creative Commons Attribution License (http://creativecommons.org/licenses/by/3.0), which permits unrestricted use, distribution, and reproduction in any medium, provided the original work is properly cited. 


\section{Introduction}

CINV is one of the most unpleasant side effects of cancer treatments experienced by cancer patients [1,2, 3]. Chemotherapy-induced emesis can cause anorexia, nutritional deficiency, metabolic imbalances, altered mental status, degeneration of self care, wound dehiscence, and esophageal tear [4]. Furthermore, its prolonged manifestation may reduce patients' quality of life (QOL) [5]. It may also lead to noncompliance of anticancer therapy with premature discontinuation [4]. As chemotherapy in a curative and palliative way is the key mode of treating cancer; preventing, minimising, and treating CINV have become an indispensable aspect of cancer chemotherapy. Although significant progress has been made in the treatment of CINV, patients undergoing chemotherapy continue to report that this side effect is persistent and distressing $[4,6,7]$.

Nausea, vomiting, and retching, although related, are actually three distinct symptoms and often go hand-in-hand [1, 8, 9]. Chemotherapyinduced emesis can be classified as acute (first 24 hours) and delayed (day 2-5) [1, 10-12]. The emetic process, triggered by chemotherapeutic agents, involves a complex network of neuroanatomical and peripheral centres, neurotransmitters, and receptors [1]. The three main neurotransmitters are serotonin/5-hydroxytryptamine (5-HT), substance P (SP), and dopamine. The receptors associated with 5-HT and SP are 5-hydroxytryptamine (5-HT3) and neurokinin-1 (NK-1) respectively [13].

Without antiemetic prophylaxis, the CINV incidence varies from 30-90\% for acute phase and $28-50 \%$ for delayed phase post moderately emetogenic chemotherapy (MEC) [14-17]. Prevention and control of acute phase CINV is linked with decreased incidence of delayed phase CINV [15]. Similarly, prevention and control of CINV in the first chemotherapy cycle leads to decreased CINV incidence in the subsequent chemotherapy cycles [18, 19]. As 5-HT3 receptors are involved in acute phase CINV, two drug therapy with 5-HT3 receptor antagonists and dexamethasone are effective in acute phase CINV [18, 20, 21]. Substance P and neurokinin-1 receptors are involved in delayed phase CINV, thus, triple drug therapy with aprepitant is used, which is effective in acute as well as delayed phase of CINV [18, 21-23]. Mostly, delayed phase CINV is underestimated by the clinicians [18, 21]. Furthermore QOL deteriorates more with delayed phase CINV, suggesting aprepitant addition for CINV control [19, 24, 25]. In Indian scenario, data suggesting aprepitant use is very limited. Therefore, the present study was undertaken to compare the efficacy, tolerability, and side effects of newer triplet antiemetic combination of palonosetron, dexamethasone, and aprepitant with the conventional doublet antiemetic combination of ondansetron and dexamethasone in patients receiving MEC for head and neck cancer.

\section{Material and methods}

\section{Patients}

This open labeled, prospective, randomised trial was conducted on sixty previously untreated histopathologically-proven patients of squamous cell carcinoma of head and neck, attending the Department of Radiotherapy, Pt. Bhagwat Dayal Sharma Post Graduate Institute of Medical Sciences, Rohtak, for definitive treatment. The tumour staging was done using the American Joint Committee on Cancer (AJCC) TNM staging system 2010 [26].

The eligibility criteria were: Karnofsky Performance Status $\geq 70$, normal complete haemogram, and blood biochemistry within normal limits. Excluded from the study were patients having: distant metastases, pregnant or lactating females, history of allergy to ondansetron, palonosetron, or aprepitant, receipt of chemotherapy during the seven days before study drug administration, any associated medical condition causing nausea/vomiting (e.g. renal, liver, or heart disease). All patients provided written informed consent.

\section{Study design and treatments}

The combination chemotherapy schedule in all patients consisted of chemotherapy with docetaxel $60 \mathrm{mg} / \mathrm{m}^{2}$ intravenously (IV), carboplatin $300 \mathrm{mg} / \mathrm{m}^{2} \mathrm{IV}$, and 5-FU (5-Fluorouracil) $600 \mathrm{mg} / \mathrm{m}^{2} \mathrm{IV}$. Planned chemotherapy was to be $\leq 4$ hours. At least seven days before chemotherapy 
administration, patients discontinued antiemetics and systemic corticosteroids (including dexamethasone). The patients were divided randomly in two groups of thirty patients each. The study group was administered with PDA antiemetic schedule (palonosetron plus dexamethasone plus aprepitant) and the control group was administered with OD schedule (ondansetron plus dexamethasone) as per the Table 1. The study was approved by the Institutional Ethical Committee and the Indian Council of Medical Research with reference number 2010-00047 Haryana.

\section{Objectives and efficacy evaluations}

The primary objective was to compare the efficacy of two antiemetic schedules i.e. palonosetron plus dexamethasone plus aprepitant versus ondansetron plus dexamethasone in patients receiving MEC for head and neck cancer. The secondary objective was to determine the tolerability and side effects of the above two antiemetic schedules. The primary efficacy end point was the CR (no emetic episodes and no use of rescue medications) during the acute (0-24 hours) and delayed (24-120 hours) phases after chemotherapy. Secondary end points included safety with $C R$ over the entire ( $0-120$ hours) period.

The antiemetic effects were evaluated by recording frequency of vomiting (acute and delayed), and intensity of nausea. The frequency of vomiting was assessed as the proportion of patients with emesis in the acute (day 1) and delayed (days 2-5) phases after chemotherapy. A single emetic episode was defined as emesis separated by less than a five minute interval. Delayed response was graded depending upon the worst observation from day 2-5. Nausea was defined by a patient's report of a feeling in the stomach that he/she may vomit.

The reporting and recording of acute nausea and vomiting were performed at the hospital, while the intensity and frequency of delayed nausea and vomiting were recorded by the relatives of the patients. Those relatives were explained about the detailed procedure. They were instructed to record the frequency of emetic episodes on the protocols provided, which were then collected at the next hospital visit. For intensity evaluation, the patients were instructed to place a finger at a point on the descriptive ordinal scale (DS), depending on the intensity of nausea felt by them. [13] Patients were given instructions to document the number of emetic episodes and nausea severity during the five day observation period after the infusion of chemotherapy. CR was defined as no emesis and no rescue medications. Assessment of antiemetic response (vomiting and nausea) was done as per criteria of Jones et al [13] as follows: Control of vomiting; CR-no emetic episode, Major response-one or two emetic episodes, Minor response-three to five emetic episodes, and Failure-more than five episodes. The intensity of nausea was evaluated on a four-point scale [27] with no nausea at one end and severe nausea (+++) at the other end. The criteria adopted for control of nausea were: no nausea (0); mild nausea $(+)$; moderate nausea $(++)$; and severe nausea $(+++)[13,27]$. Nausea severity was evaluated by using a $100 \mathrm{~mm}$ visual analog scale given to the patient. The $100 \mathrm{~mm}$ visual analog scale ranged from 0 , defined as 'no nausea', to 100 , defined as 'the worst nausea possible.' If patients ranked their nausea $0-5 \mathrm{~mm}$, it was considered 'no nausea' and if ranked 6-33 mm mild nausea, 34-66 mm moderate nausea, and 67-100 mm severe nausea. These criteria were more simple and easy to understand for the patients and relatives as they have to record the parameters for nausea and vomiting for four days from day $2-5$, while for the first day the patient was in the hospital, and so a healthcare professional was able to record both the frequency and intensity of nausea and vomiting episode [13].

Table 1. Antiemetic schedules given in PDA and OD groups $(n=60)$.

\begin{tabular}{|c|c|c|}
\hline & $\begin{array}{c}\text { PDA schedule } \\
\text { (palonosetron+ dexamethasone + } \\
\text { dprepitant) }\end{array}$ & $\begin{array}{c}\text { OD schedule } \\
\text { (ondansetron+ dexamethasone) }\end{array}$ \\
\hline Day 1 & $\begin{array}{l}\text { Half an hour before chemotherapy (CT) } \\
\text { Injection palonosetron } 0.25 \mathrm{mg} \text { IV } \\
\text { Injection dexamethasone } 12 \mathrm{mg} \text { IV } \\
\text { After CT } \\
\text { Capsule aprepitant } 125 \mathrm{mg} \text { orally OD }\end{array}$ & $\begin{array}{l}\text { Half an hour before chemotherapy } \\
\text { Injection ondansetron } 16 \mathrm{mg} \text { IV } \\
\text { Injection dexamethasone } 12 \mathrm{mg} \mathrm{IV} \\
\text { After CT } \\
\text { Tablet ondansetron } 8 \mathrm{mg} \mathrm{BD}\end{array}$ \\
\hline Day 2 & $\begin{array}{l}\text { Tablet dexamethasone } 8 \mathrm{mg} \mathrm{BD} \\
\text { Capsule aprepitant } 80 \mathrm{mg} \mathrm{OD}\end{array}$ & $\begin{array}{l}\text { Tablet dexamethasone } 8 \mathrm{mg} \text { BD } \\
\text { Tablet ondansetron } 8 \mathrm{mg} \mathrm{BD}\end{array}$ \\
\hline Day 3 & $\begin{array}{l}\text { Tablet dexamethasone } 8 \mathrm{mg} \mathrm{BD} \\
\text { Capsule aprepitant } 80 \mathrm{mg} \mathrm{OD}\end{array}$ & $\begin{array}{l}\text { Tablet dexamethasone } 8 \mathrm{mg} \text { BD } \\
\text { Tablet ondansetron } 8 \mathrm{mg} \mathrm{BD}\end{array}$ \\
\hline
\end{tabular}




\section{Safety evaluations}

Adverse events (based on standard toxicity criteria) were evaluated during each treatment cycle, including type, duration and severity (mild, moderate, severe) in relation to the study drug. Physical examinations, vital signs, and clinical laboratory parameters were also assessed.

\section{Statistical analysis}

The patients' characteristics have been summarised and tabulated using either counts and percentages for categorical data or count, mean, median, standard error, minimum, and maximum for continuous variables. The patients were categorised according to the intensity of nausea and frequency of vomiting experienced, and the results were analysed by applying the Fisher's exact test. Comparison between the groups for numeric variables was done using the Kruskal-Wallis test. The results of the study regarding safety, tolerability, toxicity, and response in both the groups were documented. Data were analysed using IBM SPSS statistics 20 software. All p-values were two sided, and a p-value $<0.05$ was considered statistically significant.

\section{Results}

Table 2 shows the characteristics of the patients included in the study. No statistically significant difference was noted in both the groups regarding characteristics of the patients. The median age was 52 years in PDA group and 51 years in OD group. The most common primary site was oropharynx in both the groups. All the patients tolerated both PDA and OD schedule well. No patient reported any untoward effect directly attributable to antiemetic drugs.

All the patients (100\%) in both the groups were able to record and report the frequency and intensity of both nausea and vomiting, as they were explained about the procedure in detail in easy and simple language. So, good compliance was seen in both the groups about the nausea and vomiting questionnaire completion. In both the groups, none of the patients was with percutaneous endoscopic gastrostomy (PEG) tube. Table 3 shows control of chemotherapy induced vomiting in both the groups. Complete antiemetic response for first 24 hours in PDA and OD group respectively was $26(86.7 \%)$ versus $18(60 \%)$, which was statistically significant as p-value was less than 0.05 . The differences for major response, minor response, and no response were not statistically significant in PDA versus OD group. Complete antiemetic response for delayed emesis (from day 2-5) in PDA and OD group respectively was 25 (83.3\%) versus 16 (53.3\%), which was statistically significant as $p$-value was less than 0.05 . Statistically significant difference was seen in PDA group as compared to OD group in terms of overall response (OR).

Table 2. Patient characteristics for both the groups included in the study $[\mathrm{n}(\%)]$.

\begin{tabular}{|l|l|c|c|}
\hline \multicolumn{2}{|c|}{ Characteristics } & PDA Group & OD Group \\
\hline Age (years) & Range & $36-70$ & $34-69$ \\
& Median & 52 & 51 \\
\hline Gender & Male & $29(96.7)$ & $23(76.7)$ \\
& Female & $1(3.3)$ & $7(23.3)$ \\
\hline Karnofsky & $\geq 80$ & $24(80)$ & $25(83.3)$ \\
Performance & $<80$ & $6(20)$ & $5(16.7)$ \\
Status & & & \\
\hline Tumour stage & III & $12(40)$ & $11(36.7)$ \\
(AJCC) & IV & $18(60)$ & $19(63.3)$ \\
\hline \multirow{4}{*}{ Primary site } & Oral cavity & $3(10)$ & $5(16.7)$ \\
& Oropharynx & $18(60)$ & $15(50)$ \\
& Nasopharynx & $1(3.3)$ & 0 \\
& Larynx & $5(16.7)$ & $6(20)$ \\
& Hypopharynx & $3(10)$ & $4(13.3)$ \\
\hline
\end{tabular}


Table 3. Comparison of chemotherapy induced vomiting control in both the groups as PDA versus OD group [ $n(\%)]$.

\begin{tabular}{|c|c|c|c|c|}
\hline & $\begin{array}{l}\text { Antiemetic } \\
\text { response } \\
\text { Jones et } a I^{10}\end{array}$ & $\begin{array}{c}\text { Acute phase } \\
\text { (day 1) } \\
\text { No. (\%) }\end{array}$ & $\begin{array}{l}\text { Delayed phase } \\
\text { (day 2-5)* } \\
\text { No. }(\%)\end{array}$ & $\begin{array}{l}\text { Overall Response } \\
\text { (Day 1-5) } \\
\text { No. (\%) }\end{array}$ \\
\hline $\begin{array}{l}\text { Complete } \\
\text { response }\end{array}$ & No emetic episode & $\begin{array}{l}26(86.7 \%) \text { versus } \\
18(60 \%) \\
p=0.01, \text { significant }\end{array}$ & $\begin{array}{l}25(83.3 \%) \text { versus } \\
16(53.3 \%) \\
p=0.01, \text { significant }\end{array}$ & $\begin{array}{l}25(83.3 \%) \text { versus } \\
16(53.3 \%) \\
p=0.01, \text { significant }\end{array}$ \\
\hline Major response & $\begin{array}{l}1-2 \text { emetic } \\
\text { episodes }\end{array}$ & $\begin{array}{l}4(13.3 \%) \text { versus } \\
9(30 \%) \\
p=0.12, N^{* *}\end{array}$ & $\begin{array}{l}5(16.6 \%) \text { versus } \\
8(26.6 \%) \\
p=0.35, N^{* *}\end{array}$ & $\begin{array}{l}4(13.3 \%) \text { versus } \\
6(20 \%) \\
p=0.49, N S\end{array}$ \\
\hline Minor response & $\begin{array}{l}3-5 \text { emetic } \\
\text { episodes }\end{array}$ & $\begin{array}{l}0(0 \%) \text { versus } \\
2(6.6 \%) \\
p=0.15, N^{* *}\end{array}$ & $\begin{array}{l}0(0 \%) \text { versus } \\
4(13.3 \%) \\
p=0.03, \text { significant }\end{array}$ & $\begin{array}{l}01(3.33 \%) \text { versus } \\
5(16.7 \%) \\
p=0.08, N^{* *}\end{array}$ \\
\hline No response & $>5$ emetic episodes & $\begin{array}{l}0(0 \%) \text { versus } 1(3.3 \%) \\
p=0.31, N S^{* *}\end{array}$ & $\begin{array}{l}0(0 \%) \text { versus } 2(6.6 \%) \\
p=0.15, N^{* *}\end{array}$ & $\begin{array}{l}0(0 \%) \text { versus } 3(10 \%) \\
p=0.07, N^{* *}\end{array}$ \\
\hline
\end{tabular}

* Delayed response is graded depending upon the worst observation from day 2-5.

${ }^{* *} \mathrm{NS}=$ Not significant

Table 4. Comparison of chemotherapy induced nausea control in both the groups as PDA versus OD group [n(\%)].

\begin{tabular}{|c|c|c|c|}
\hline Schedule & $\begin{array}{c}\text { Acute phase } \\
\text { (day 1) } \\
\text { No. (\%) }\end{array}$ & $\begin{array}{l}\text { Delayed phase } \\
\text { (day } 2-5)^{*} \\
\text { No. }(\%)\end{array}$ & $\begin{array}{c}\text { Overall response } \\
\text { (day 1-5) } \\
\text { No. (\%) }\end{array}$ \\
\hline No nausea & $\begin{array}{l}21(70 \%) \text { versus } \\
14(46.6 \%) \\
p=0.06, N^{* *}\end{array}$ & $\begin{array}{l}23(76.6 \%) \text { versus } \\
13(43.3 \%) \\
p<0.05, \text { significant }\end{array}$ & $\begin{array}{l}21(70 \%) \text { versus } \\
13(43.3 \%) \\
p=0.04, \text { significant }\end{array}$ \\
\hline $\begin{array}{l}\text { Mild nausea } \\
(+)\end{array}$ & $\begin{array}{l}6(20 \%) \text { versus } \\
9(30 \%) \\
p=0.37, N^{* *}\end{array}$ & $\begin{array}{l}6(20 \%) \text { versus } \\
9(30 \%) \\
p=0.37, N^{* *}\end{array}$ & $\begin{array}{l}6(20 \%) \text { versus } \\
9(30 \%) \\
p=0.37, N^{* *}\end{array}$ \\
\hline $\begin{array}{l}\text { Moderate } \\
\text { nausea (++) }\end{array}$ & $\begin{array}{l}3(10 \%) \text { versus } \\
5(16.6 \%) \\
p=0.95, N^{* *}\end{array}$ & $\begin{array}{l}1(3.3 \%) \text { versus } \\
6(20 \%) \\
p=0.44, N^{* *}\end{array}$ & $\begin{array}{l}2(6.7 \%) \text { versus } \\
6(20 \%) \\
p=0.13, N^{* *}\end{array}$ \\
\hline $\begin{array}{l}\text { Severe nausea } \\
(+++)\end{array}$ & $\begin{array}{l}0 \text { versus } 2(6.6 \%) \\
p=0.15, N S^{* *}\end{array}$ & $\begin{array}{l}0 \text { versus } 2(6.6 \%) \\
p=0.15, N S^{* *}\end{array}$ & $\begin{array}{l}1(3.3 \%) \text { versus } \\
2(6.6 \%) \\
p=0.55, N^{* \star}\end{array}$ \\
\hline
\end{tabular}

${ }^{*}$ Delayed response is graded depending upon the worst response from day $2-5$.

${ }^{* *} \mathrm{NS}=$ Not significant

Table 4 shows the control of chemotherapy induced nausea in both the groups. For first 24 hours, in acute phase, no nausea was noted in $21(70 \%)$ versus $14(46.6 \%)$ in PDA and OD group respectively, which was statistically not significant. The mild, moderate, and severe nausea were statistically not significant in PDA group as in comparison to OD group for first 24 hours. No nausea in delayed phase from day $2-5$ in PDA and OD group respectively was $23(76.6 \%)$ versus $13(43.3 \%)$, which was statistically significant $(p<0.05)$. No statistically significant difference was seen for mild, moderate, and severe nausea in the PDA group as compared to OD group.

The CR to both acute and delayed emesis (no vomiting from day 1-5) in PDA and OD group respectively was 25 (83.3\%) versus 16 (53.3\%) with $p$-value $<0.05$, which is shown in Figure 1. The CR to nausea (no nausea from day 1-5) in PDA and OD group respectively was $21(70 \%)$ versus $13(43.3 \%)$ with $p$-value $<0.05$, which is shown in Figure 1.

Both the antiemetic schedules were well tolerated by the patients without significant treatment-related toxicity. 


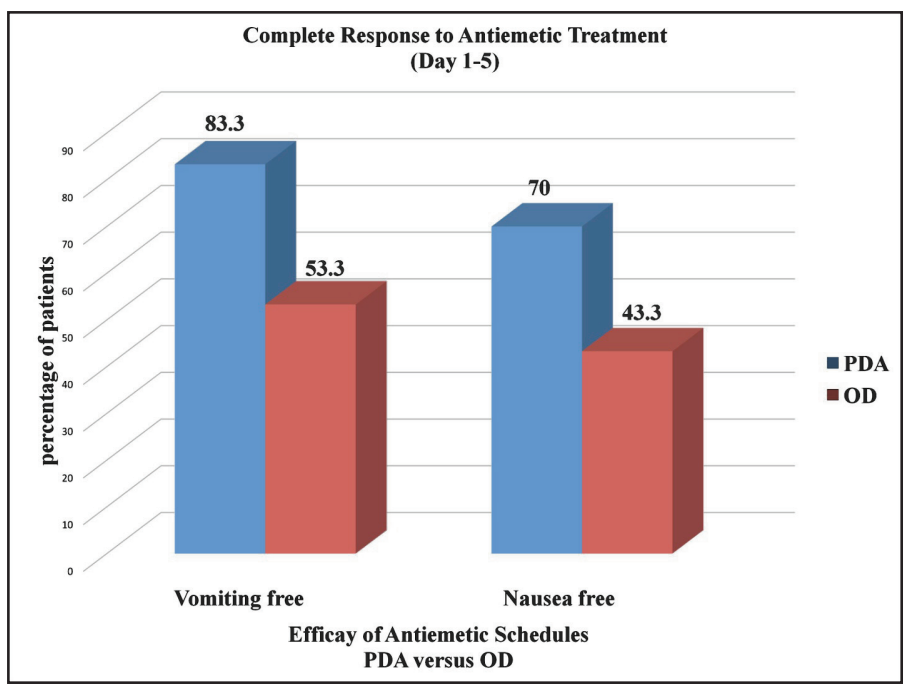

Figure 1. Graph showing CR to antiemetic treatment with PDA versus OD schedule.

\section{Discussion}

In this open labeled, prospective CINV prophylaxis study in Indian patients with head and neck cancer, triplet antiemetic therapy with aprepitant, palonosetron, and dexamethasone, was associated with high CR (complete response) rates over doublet antiemetic therapy with ondansetron and dexamethasone, in both acute as well as delayed phases of CINV after administration of MEC with docetaxel, carboplatin, and 5-FU. In accordance with the National Comprehensive Cancer Network (NCCN) 2014 guidelines, in the present study, palonosetron was not followed by 5-HT3 antagonist post day one; only dexamethasone and aprepitant were administered post day one in PDA schedule as per the dosage prescribed by NCCN. Similarly, ondansetron and dexamethasone were administered in OD schedule in acute as well as delayed phases as per the NCCN antiemetic guidelines.[28] According to NCCN guidelines, antiemetic regimens should be chosen based on the drug with highest emetic risk. The combination chemotherapy consisting of docetaxel, carboplatin, and 5-FU which we used here is a moderately emetogenic regimen as carboplatin is a moderately emetogenic drug [28].

The data available are very limited regarding the CINV risk and antiemetic regimen efficacy in Indian patients after administration of the MEC regimen in head and neck cancer. The present study compares palonosetron and aprepitant containing group directly to ondansetron containing group. It is the first kind of this study in the Indian population. For standard antiemetic combination of ondansetron and dexamethasone (OD schedule), the protection remains largely limited to acute phase with little or no effect over delayed phase of CINV. For the treatment of chemotherapy-induced emesis, the U.S. Food and Drug Administration approved two novel agents, palonosetron, a longer-acting serotonin antagonist, and aprepitant, a neurokinin-1 antagonist [13]. For a triplet chemotherapy regimen, there is no established antiemetic schedule.

In the present study, the PDA group was well tolerated and yielded statistically significant results as compared to OD schedule in controlling CINV in acute $(86.7 \%$ versus $60 \%$ ) as well as delayed phase (83.3\% versus $53.3 \%)$. Palonosetron is a newer, potent, and selective second generation 5-HT3 receptor antagonist and is useful for the prevention of delayed CINV in patients receiving MEC [13]. Phase III trials have demonstrated that a single dose of palonosetron compared with traditional 5-HT3 receptor antagonists is more effective in preventing acute CINV, and it also exhibits prolonged efficacy to provide significantly better protection from CINV in the delayed and overall phases as shown in a meta-analysis by Botrel et al in 2010 [29]. Less nausea was noted in both acute $(R R=0.86)$ and delayed $(R R=0.82)$ phases among patients in palonosetron group [28]. They also had less acute vomiting (RR 0.76) and delayed vomiting $(R R=0.76)$ [29]. Hajdenberg et al demonstrated CR rates of $84 \%$ in acute phase and $59 \%$ in delayed phase CINV for palonosetron, which is similar to our study [30]. 
In the present study, dexamethasone was administered in both the groups as per the dosage schedule of NCCN 2014. It has been shown that the antiemetic potential of palonosetron is significantly increased when combined with dexamethasone [28]. On combining aprepitant to palonosetron and dexamethasone in PDA group, significant improvement was noted in delayed phases of CINV. Aprepitant, a recently approved drug, antagonises the effect of substance $P$ on neurokinin type 1 receptors [22, 23]. It has shown promising results in controlling both phases of CINV [22, 23]. The addition of aprepitant, to an antiemetic combination improves control of emesis by a further $15-20 \%$ and improves late phase symptoms (>24 hours after chemotherapy) [22, 23]. Aprepitant inhibits CYP3A4 and in turn inhibits the metabolism of dexamethasone. So, to maintain dexamethasone at the prescribed blood level in the presence of aprepitant, the dose of dexamethasone has to be reduced by $50 \%$ [31]. Although a previous population pharmacokinetic study of dexamethasone combined with aprepitant supported the validity of this dose reduction of dexamethasone, there has been no full pharmacokinetic study of dexamethasone and aprepitant in cancer patients who receive emetogenic cancer chemotherapy [32, 33].

In the present study, the proportion of patients who remained emesis free was significantly higher with the aprepitant and palonosetron containing regimen than with the active control $(83.3 \%$ versus $53.3 \%)$ which is similar to the CR reported in medical literature $(35.7-93 \%$ versus 5.6-66.4\% respectively) [34-38]. According to Warr et al, the proportion of patients who remained emesis free was significantly higher with the aprepitant containing regimen than with the active control $(70.2-82.8 \%$ versus $38.6-66.4 \%$ respectively) [34]. A KCOG-G1003 reported emesis free rate in overall phase, acute phase, and delayed phase as $54.2 \%, 87.5 \%$, and $56.3 \%$ respectively. These results for emesis control for nausea and vomiting are similar to our study [39].

The present study has shown nausea free rate of $70 \%$ in aprepitant containing arm, which is comparable to $59.9 \%$ reported by Longo et al and $66.7 \%$ by Gore et al respectively [35, 37]. Similar results for nausea control have been reported in other studies where aprepitant or palonosetron has been used [40-43]. Rojas et al reported a study on molecular mechanisms of 5-HT(3) and NK(1) receptor antagonists in prevention of emesis [43]. Aprepitant not only reduced acute emesis but also helped in the reduction of delayed emesis [43].

Both the groups are cost effective as per the World Health Organisation (WHO) cost effective and strategic planning guidelines. In an Indian scenario, the cost of PDA group is much more than that of the OD group. But, as the PDA group is more effective in controlling CINV, PDA group is affordable. Recent research for management of chemotherapy-induced nausea and vomiting has focused on optimisation of palonosetron and aprepitant-based antiemetic regimens, particularly in combination with steroids. These have shown complete emesis control varying from $35.7-93 \%$ in various studies [34-43]. The study was limited by small sample size which further necessitates the need of a large randomised study trial to confirm the benefits of MEC drug combination regimens.

\section{Conclusion}

In conclusion, the present study has shown that an antiemetic schedule comprising of palonosetron, aprepitant, and dexamethasone was better than the combination of ondansetron and dexamethasone in controlling cancer CINV in the acute as well as delayed phases post MEC in head and neck cancer. Both the antiemetic combinations were well tolerated by patients with no augmentation of any adverse drug interaction with co-prescribed medications in patients receiving chemotherapy. Future research should be focused on a large randomised trial including a larger number of patients to consolidate the benefits.

\section{Conflicts of interest}

The authors have no conflicts of interest to declare.

\section{References}

1. Janelsins MC et al (2013) Current Pharmacotherapy for Chemotherapy-Induced Nausea and Vomiting in Cancer Patients Expert Opin Pharmacother 14(6) 757-66 DOI: 10.1517/14656566.2013.776541 PMID: 23496347 PMCID: $\underline{3938333}$ 
2. Hickok JT, Roscoe JA and Morrow GR et al (2005) 5-Hydroxytryptamine-receptor antagonists versus prochlorperazine for control of delayed nausea caused by doxorubicin: a URCC CCOP randomized controlled trial Lancet Oncol 6(10) 765-72 DOI: $\underline{10.1016 / S 1470-2045(05) 70325-9}$ PMID: 16198982 PMCID: $\underline{1646426}$

3. Hofman M, Morrow GR and Roscoe JA et al (2004) Cancer patients' expectations of experiencing treatment related side effects: a University of Rochester Cancer Center-Community Clinical Oncology Program study of $\mathbf{9 3 8}$ patients from community practices Cancer 101(4) 851-7 DOI: $10.1002 /$ cncr.20423 PMID: $\underline{15305419}$

4. Affronti ML and Bubalo J (2014) Palonosetron in the management of chemotherapy-induced nausea and vomiting in patients receivingmultiple-day chemotherapy Cancer Management Res 6 329-37 DOI: 10.2147/CMAR.S68102

5. Uchino J et al (2012) Efficacy of Aprepitant in Patients with Advanced or Recurrent Lung Cancer Receiving Moderately Emetogenic Chemotherapy Asian Pacific J Cancer Prev 13(8) 4187-90 DOI: 10.7314/APJCP.2012.13.8.4187

6. Nandeesh BR and Reddy TM (2012) Chemotherapy induced nausea \& vomiting (CINV) Int J Basic Clin Pharmacol 1(3) 125-31 DOI: $10.5455 / 2319-2003 . i j b c p 002512$

7. Wickham R (2010) Best practice management of CINV in oncology patients: II. Antiemetic guidelines and rationale for use J Support Oncol 8(2 Suppl 1) 10-5 PMID: 20629453

8. Wilhelm SM, Dehoorne-Smith ML and Kale-Pradhan PB (2007) Prevention of postoperative nausea and vomiting Ann Pharmacother 41(1) 68-78 DOI: 10.1345/aph.1H398 PMID: 17200430

9. Rhodes VA and McDaniel R (2001) Nausea, vomiting, and retching: complex problems in palliative care CA Cancer J Clin 51(4) 232-48 DOI: 10.3322/canjclin.51.4.232 PMID: 11577489

10. Basch E, Prestrud AA and Hesketh PJ et al (2011) Antiemetics: American society of clinical oncology clinical practice guideline update J Clin Oncol 29(31) 4189-98 DOI: 10.1200/JCO.2010.34.4614 PMID: 21947834

11. Durand JP, Madelaine I and Scotte F (2009) Guidelines for prophylaxis and treatment of chemotherapy induced nausea and vomiting Bull Cancer 96(10) 951-60 PMID: 19734117

12. Roila F, Boschetti $E$ and Tonato $M$ et al (1991) Predictive factors of delayed emesis in cisplatintreated patients and antiemetic activity and tolerability of metoclopramide or dexamethasone. A randomized single-blind study Am J Clin Oncol 14(3) 238-42 DOI: 10.1097/00000421-199106000-00010 PMID: 2031511

13. Kaushal J et al (2010) Clinical evaluation of two antiemetic combinations palonosetron dexamethasone versus ondansetron dexamethasone in chemotherapy of head and neck cancer Singapore Med J 51(11) 871-5 PMID: 21140114

14. Hingmire $S$ and Raut $N$ (2015) Open-label observational study to assess the efficacy and safety of aprepitant for chemotherapyinduced nausea and vomiting prophylaxis in Indian patients receiving chemotherapy with highly emetogenic chemotherapy/ moderately emetogenic chemotherapy regimens South Asian J Cancer 4(1) 7-10 DOI: 10.4103/2278-330X.149923 PMID: 25839011 PMCID: 4382794

15. Gilmore JW et al (2014) Antiemetic guideline consistency and incidence of chemotherapy-induced nausea and vomiting in US community oncology practice: INSPIRE Study J Oncol Pract 10(1) 68-74 DOI: $\underline{10.1200 / J O P .2012 .000816}$

16. Longo $\mathrm{F}$ et al (2012) Combination of aprepitant, palonosetron and dexamethasone as antiemetic prophylaxis in lung cancer patients receiving multiple cycles of cisplatin-based chemotherapy Int J Clin Pract 66(8) 753-57 DOI: 10.1111/j.17421241.2012.02969.x PMID: 22805267 PMCID: $\underline{3437500}$

17. Grunberg SM et al (2004) Incidence of chemotherapy-induced nausea and emesis after modern antiemetics Cancer 100(10) 2261-8 DOI: $10.1002 / \mathrm{cncr} .20230$ PMID: 15139073

18. Ito $Y$ et al (2014) Aprepitant in patients with advanced non-small-cell lung cancer receiving carboplatin-based chemotherapy Lung Cancer 84(3) 259-64 DOI: 10.1016/j.lungcan.2014.03.017 PMID: 24746177 
19. Hesketh PJ et al (2003) The oral neurokinin-1 antagonist aprepitant for the prevention of chemotherapy-induced nausea and vomiting: A multinational, randomized, double-blind, placebo-controlled trial in patients receiving high-dose cisplatin - the Aprepitant Protocol 052 Study Group J Clin Oncol 21(22) 4112-9 DOI: 10.1200/JCO.2003.01.095 PMID: 14559886

20. Herrington JD, Jaskiewicz AD and Song J (2008) Randomized, placebo-controlled, pilot study evaluating aprepitant single dose plus palonosetron and dexamethasone for the prevention of acute and delayed chemotherapy-induced nausea and vomiting Cancer 112(9) 2080-7 DOI: $\underline{10.1002 / \text { cncr.23364 PMID: } 18327813}$

21. Jordan $\mathrm{K}$ et al (2011) The NK-1 receptor-antagonist aprepitant in high-dose chemotherapy (high-dose melphalan and highdose T-ICE: Paclitaxel, ifosfamide, carboplatin, etoposide): Efficacy and safety of a triple antiemetic combination Bone Marrow Transplant 46(6) 784-9 DOI: $10.1038 / \mathrm{bmt} .2010 .205$

22. De Wit $\mathrm{R}$ (2003) Current position of $5 \mathrm{HT} 3$ antagonists and the additional value of NK1 antagonists: A new class of antiemetics Br J Cancer 88(12) 1823-7 DOI: 10.1038/sj.bjc.6601033 PMID: 12799621 PMCID: 2741127

23. Massaro AM and Lenz KL (2005) Aprepitant: A novel antiemetic for chemotherapy-induced nausea and vomiting Ann Pharmacother 39(1) 77-85 DOI: 10.1345/aph.1E242

24. Bloechl-Daum B et al (2006) Delayed nausea and vomiting continue to reduce patients' quality of life after highly and moderately emetogenic chemotherapy despite antiemetic treatment $J$ Clin Oncol 24(27) 4472-8 DOI: 10.1200/JC0.2006.05.6382 PMID: $\underline{16983116}$

25. Poli-Bigelli $S$ et al (2003) Addition of the neurokinin 1 receptor antagonist aprepitant to standard antiemetic therapy improves control of chemotherapy-induced nausea and vomiting. Results from a randomized, double-blind, placebo-controlled trial in Latin Cancer 97(12) 3090-8 DOI: 10.1002/cncr.11433 PMID: 12784346

26. Edge SB et al (2010) AJCC Cancer Staging Manual

27. Hesketh PJ et al (1997) Proposal for classifying the acute emetogenicity of cancer chemotherapy J Clin Oncol 15(1) 103-9 PMID: 8996130

28. Celio L et al (2008) Clinical update on palonosetron in the management of chemotherapy-induced nausea and vomiting Tumori 94(4) 447-52 PMID: 18822676

29. Botrel TE et al (2010) Efficacy of palonosetron (PAL) compared to other serotonin inhibitors (5-HT(3)R) in preventing chemotherapy-induced nausea and vomiting (CINV) in patients receiving moderately or highly emetogenic (MoHE) treatment: systematic review and meta-analysis Support Care Cancer 19(6) 823-32 (Epub ahead of print) DOI: 10.1007/s00520-010-0908-8 PMID: 20495832

30. Hajdenberg J et al (2006) Infusion of palonosetron plus dexamethasone for the prevention of chemotherapy-induced nausea and vomiting $J$ Support Oncol 4(9) 467-71 PMID: 17080735

31. McCrea JB et al (2003) Effects of the neurokinin1 receptor antagonist aprepitant on the pharmacokinetics of dexamethasone and methylprednisolone Clin Pharmacol Ther 74(1) 17-24 DOI: 10.1016/S0009-9236(03)00066-3 PMID: 12844131

32. Nakade $\mathrm{S}$ et al (2008) Population pharmacokinetics of aprepitant and dexamethasone in the prevention of chemotherapyinduced nausea and vomiting. Cancer Chemother Pharmacol 63(1) 75-83 DOI: 10.1007/s00280-008-0713-y PMID: 18317761

33. Takahashi T et al (2011) Pharmacokinetics of aprepitant and dexamethasone after administration of chemotherapeutic agents and effects of plasma substance $P$ concentration on chemotherapy-induced nausea and vomiting in Japanese cancer patients Cancer Chemother Pharmacol 68(3) 653-59 DOI: 10.1007/s00280-010-1519-2 PMCID: $\underline{3162145}$

34. Warr DG, Street JC and Carides AD (2010) Evaluation of risk factors predictive of nausea and vomiting with current standardof-care antiemetic treatment: analysis of phase 3 trial of aprepitant in patients receiving adriamycin-cyclophosphamidebased chemotherapy Support Care Cancer 19(6) 807-13 (Epub ahead of print) DOI: 10.1007/s00520-010-0899-5 PMID: 20461438 
35. Miura S et al (2013) The efficacy of triplet antiemetic therapy with $\mathbf{0 . 7 5} \mathbf{~ m g}$ of palonosetron for chemotherapy-induced nausea and vomiting in lung cancer patients receiving highly emetogenic chemotherapy Support Care Cancer 21(9) 2575-81 DOI: 10.1007/s00520-013-1835-2 PMID: 23644992

36. Longo $\mathrm{F}$ et al (2011) Palonosetron plus 3-day aprepitant and dexamethasone to prevent nausea and vomiting in patients receiving highly emetogenic chemotherapy Support Care Cancer 19(8) 1159-64 DOI: $10.1007 / 500520-010-0930-x$

37. Gore L, Chawla S and Petrilli A et al (2009) Aprepitant in adolescent patients for prevention of chemotherapy-induced nausea and vomiting: a randomized, double-blind, placebo-controlled study of efficacy and tolerability Pediatr Blood Cancer 52(2) 242-7 DOI: $10.1002 / p b c .21811$

38. Takeshima $\mathrm{N}$ et al (2014) Efficacy and safety of triple therapy with aprepitant, palonosetron, and dexamethasone for preventing nausea and vomiting induced by cisplatin-based chemotherapy for gynecological cancer: KCOG-G1003 phase II trial Support Care Cancer 22(11) 2891-8 [Epub ahead of print] DOI: 10.1007/s00520-014-2280-6 PMID: 24825735

39. Hamada S et al (2014) Antiemetic efficacy and safety of a combination of palonosetron, aprepitant, and dexamethasone in patients with testicular germ cell tumor receiving 5-day cisplatin-based combination chemotherapy Support Care Cancer 22(8) 2161-6 [Epub ahead of print] DOI: $\underline{10.1007 / s 00520-014-2182-7}$ PMID: $\underline{24652048}$

40. Gralla RJ et al (2014) A phase III study evaluating the safety and efficacy of NEPA, a fixed-dose combination of netupitant and palonosetron, for prevention of chemotherapy-induced nausea and vomiting over repeated cycles of chemotherapy Ann Oncol 25(7) 1333-9 DOI: 10.1093/annonc/mdu096 PMID: 24631949 PMCID: 4071753

41. Roila F et al (2014) Aprepitant versus dexamethasone for preventing chemotherapy-induced delayed emesis in patients with breast cancer: a randomized double-blind study J Clin Oncol 32(2) 101-6 DOI: 10.1200/JCO.2013.51.4547

42. Rojas C, Raje M and Tsukamoto T et al (2014) Molecular mechanisms of 5-HT(3) and NK(1) receptor antagonists in prevention of emesis Eur J Pharmacol 722 26-37 DOI: 10.1016/j.ejphar.2013.08.049

43. Osawa H, Goto H and Myojo $\mathrm{T}$ (2013) Comparison of antiemesis effects of granisetron, aprepitant and dexamethasone topalonosetron, aprepitant and dexamethasone in treatment of high-emetic risk chemotherapy-induced nausea and vomiting a retrospective study for efficacy and safety in a single institute Gan To Kagaku Ryoho 40(5) 617-21 PMID: 23863585 